\title{
Antibacterial activities of wild rhizomatous plants - Curcuma aromatica, Curcuma longa (Zingiberaceae) and synergistic effects of both collected from southern Western Ghats, India
}

\author{
R. Suresh ${ }^{1,3}$, , S. Thampiraj ${ }^{2}$, and A. Stephen ${ }^{3}$ \\ ${ }^{1}$ Department of Botany, Scott Christian College (Autonomous), Nagercoil, India \\ ${ }^{2}$ Department of Botany, Scott Christian College (Autonomous), Nagercoil, India \\ ${ }^{3}$ Department of Botany, Ramakrishna Mission Vivekananda College (Autonomous), Mylapore, India \\ *Corresponding Author: chavalsur15@gmail.com, Tel.: +91-79044-10010
}

Available online at: www.isroset.org

Received: 08/Mar/2018, Revised: 17/Mar/2018, Accepted: 14/Apr/2018, Online: 30/Apr/ 2018

\begin{abstract}
Rhizome extracts of Curcuma aromatica and Curcuma longa (Zingiberaceae) from southern Western Ghats of Tamil Nadu, India were investigated for their antibacterial activity by agar well diffusion method against bacterial human pathogens such as Escherichia coli, $\beta$-haemo streptococci, Klebsiella penumoniae, Staphylococcus aureus, Salmonella typhi, Bacillus subtilis and Pseudomonas aeruginosa. The study revealed that except Pseudomonas aeruginosa, all the pathogens were inhibited by various extracts (Methanol, Ethanol, n-Butanol and Acetone) of Curcuma spp. sometimes far better than the control antibiotic Amoxicillin. Pseudomonas aeruginosa was inhibited by n-Butanol extract of $C$. longa as equal as standard antibiotic. These results clearly elucidates that Curcuma aromatica and Curcuma longa collected from wild have higher antibacterial activity than that of standard antibiotic.
\end{abstract}

Keywords-Antibacterial activity, Curcuma aromatica, Curcuma longa, Western Ghats

\section{INTRODUCTION}

Curcuma longa L. (syn. C. domestica Vahl.) is a perennial rhizomatous herb of the family Zingiberaceae. The rhizome is the source of turmeric, which has use as a condiment and coloring agent in medicines, confectionery and curry powder [1]. The extracts of turmeric roots has traditionally been used as an insect repellent, antimicrobial [2], antidiabetic [3], rheumatism, bodyache, skin diseases, intestinal worms, diarrhea, intermittent fever, hepatic disorders, biliousness, urinary discharges, dyspepsia, inflammations, constipation, leukoderma, amenorrhea and colic inflammatory disorders [4]. The most important compounds responsible for the antioxidant activity of turmeric are phenolic compounds, such as curcuminoid dyes and essential oils [5]. Traditionally, the leaves of $C$. longa extensively used in culinary preparation are aromatic and contain essential oil. $C$. longa leaves oil bestowed with medicinal values has been used for treatment of various ailments and many of its therapeutic properties have been experimentally validated including its antimicrobial activity [6-7]. Therefore, much attention has been focused on application of plant derived antimicrobials to control pathogens in foods. Consequently, alternative additives are needed, which possess antimicrobial activity and cause no health problems [8-11].

Curcuma aromatica belongs to the family Zingiberaceae and is distributed throughout India and is widely used as a flavouring agent, Condiment and a source of yellow dye. Rhizomes are aromatic and pungent with a ginger - sour lemon flavour. It is a perennial tuberous herb, flowers pink, lip yellow, obovate, subentive or obscurely three lobed, fruit dehiscent globose three valved capsules. The rhizomes and roots are frequently used in cosmetics and spas for skin nourishment. There are many literatures reporting the medicinal values of Curcuma longa and Curcuma aromatica. On the other hand, emergence of new disease, development of Multi Drug Resistance (MDR) among pathogens and tumorous cells have resulted in ineffective treatment. This imbalance has pushed the pharmaceutical sector for the discovery of novel drugs from wild plants. Hence, this paper attempts to show the antimicrobial potential of these two wild plants collected from southern Western Ghats.

\section{Materials AND MethodS}

Plant collection and extraction 
The rhizomatous plants were collected randomly from the regions where plenty of water is present. Curcuma aromatica and Curcuma longa were collected for the study of antibacterial activity from southern Western Ghats. Of these two species, Curcuma longa collected from Kulasekharam and Curcuma aromatica collected from Muttaikadu of Kanyakumari district of Tamil Nadu, India. The plant species were collected by hand or by using a knife. The plant species were transported to the laboratory in polythene bags. The unwanted plant materials were removed by using knife and the rhizome part is taken and washed with fresh water to remove the soil particles.

\section{Extraction of compounds}

The extraction was carried out with different solvents such as Methanol, Ethanol, n-Butyl alcohol and Acetone. Ten gram of the dried powder was soaked in $50 \mathrm{ml}$ of different solvents with periodic shaking at room temperature. The extraction with different solvents were carried out individually for each sample. Each extracts were filtered through muslin cloth and collected in separate test tubes.

\section{Test on human pathogens}

The bacterial strains were identified strains, which obtained from Scudder laboratory, Nagercoil. The bacterial strains used for the study were Escherichia coli, $\beta$-haemo streptococci, Klebsiella penumoniae, Staphylococcus aureus, Salmonella typhi, Bacillus subtilis and Pseudomonas aeruginosa.

\section{Preparation of test microorganisms}

A loop full of the bacterial strains were inoculated in $20 \mathrm{ml}$ of nutrient broth kept in a conical flask and incubated at $37^{\circ} \mathrm{C}$ for 18 hours to activate the bacterial strains. This was used as inoculums for the further study.

\section{Preparation of natural disc}

Sterile discs were obtained and stored at $4^{\circ} \mathrm{C}$. Discs were handled using a pair of presterilized forceps. The extract was loaded on to the disc carefully using capillary tube, without spreading out. Thus, the disc completely saturated with the extract was used for testing antibacterial activity.

\section{Culture of Test microorganisms}

Solid media of nutrient agar was prepared by dissolving 2.8 gm of nutrient agar in $100 \mathrm{ml}$ of distilled water. About $25 \mathrm{ml}$ of nutrient agar media was poured in to a petridish, allowed to solidify. The inoculum of bacteria was transferred to petriplates containing solid nutrient agar media using a sterile swab.

\section{Implementation of disc}

Antibacterial activity was evaluated using agar disc diffusion technique. When the culture medium was solidified, dried test discs impregnated with extracts and synthetic discs were transferred on bacterial lawn under aseptic conditions using spirit flame sterilized forceps. The petridish was incubated at room temperature for 24 hours. The resulting, zones of inhibition around the disc were observed and recorded as positive and negative results. The inhibitory zone around the discs indicates absence of bacterial growth and was recorded as positive test $(+)$, the absence of zones as negative test $(-)$.

\section{RESUlts AND DiscuSSION}

Extract of Curcuma aromatica using Ethanol, Methanol, nButyl alcohol and Acetone showed varying activities. A perusal of Table 1 indicates the varied activities as measured by zone of inhibition with extracts made with Ethanol on selected human pathogens such as Escherichia coli (10 mm), $\beta$-haemo streptococci $(20 \mathrm{~mm})$, Klebsiella pneumoniae (10 $\mathrm{mm})$, Staphylococcus aureus $(10 \mathrm{~mm})$, Salmonella typhi (10mm), Bacillus subtilis $(10 \mathrm{~mm})$ and Pseudomonas aeruginosa (10mm) (Figure - 2). Moreover, the zone of inhibition measured with Methanol extract on Escherichia coli $(10 \mathrm{~mm}), \beta$-haemo streptococci $(15 \mathrm{~mm})$, Klebsiella pneumoniae $(10 \mathrm{~mm})$. Staphylococcuis aureus $(10 \mathrm{~mm})$, Salmonella typhi (10mm), Bacillus subtilis (15 $\mathrm{mm})$ and Pseudomonas aeruginosa (12mm) (Figure - 1). The zone obtained from inhibition measured with n-Butyl alcohol extract Escherichia coli (15 mm), $\beta$-haemo streptococci (10mm), Klebsiella pneumoniae $(10 \mathrm{~mm})$, Staphylococcus aureus $(15 \mathrm{~mm})$, Salmonella typhi $(10 \mathrm{~mm})$, Baciluus subtilis (10mm) and Pseudomonas aeruginosa (10mm) (Figure - 3). As well as, the zone of inhibition measures with Acetone extract on Escherichia coli $(10 \mathrm{~mm}), \beta$-haemo streptococci (10mm), Klebsiella pneumoniae (10mm), Staphylococcus aureus $(15 \mathrm{~mm})$, Salmonella typhi $(10 \mathrm{~mm})$, Bacillus subtilis $(10 \mathrm{~mm})$ and Pseudomonas aeruginosa $(10 \mathrm{~mm})$ (Figure 4). All the extracts of $C$. aromatica were inhibiting pathogens effectively.

Table 1. Growth Inhibition of Human pathogenic Bacteria by Rhizome extracts of Curcuma aromatica and Curcuma longa (diameter of zone in $\mathrm{mm}$ )

\begin{tabular}{|c|c|c|c|c|c|}
\hline $\begin{array}{c}\text { Human } \\
\text { Pathogens }\end{array}$ & Solvents & $\begin{array}{c}C . \\
\text { aromatica }\end{array}$ & $\begin{array}{c}\text { C. } \\
\text { longa }\end{array}$ & $\begin{array}{c}\text { C. aromatica } \\
\text { with } C . \\
\text { longa }\end{array}$ & $\begin{array}{l}\text { Amoxi } \\
\text { cillin }\end{array}$ \\
\hline \multirow{4}{*}{$\begin{array}{c}\text { Escherchia } \\
\text { coli }\end{array}$} & $\mathrm{Mt}$ & 10 & 20 & 10 & \multirow{4}{*}{19} \\
\hline & Et & 10 & - & - & \\
\hline & n-But & 15 & 25 & 12 & \\
\hline & Ac & 10 & - & - & \\
\hline \multirow{4}{*}{$\begin{array}{c}\beta \text {-haemo } \\
\text { streptococci }\end{array}$} & $\mathrm{Mt}$ & 15 & 9 & 10 & \multirow{4}{*}{-} \\
\hline & Et & 20 & 11 & 15 & \\
\hline & n-But & 10 & 13 & 10 & \\
\hline & Ac & 10 & 9 & 23 & \\
\hline \multirow{4}{*}{$\begin{array}{c}\text { Klebsiella } \\
\text { pneumoniae }\end{array}$} & Mt & 10 & 7 & 12 & \multirow{4}{*}{12} \\
\hline & $\mathrm{Et}$ & 10 & - & 10 & \\
\hline & n-But & 10 & - & 15 & \\
\hline & Ac & 10 & - & 10 & \\
\hline \multirow{3}{*}{$\begin{array}{c}\text { Staphylococ } \\
\text { cus aureus }\end{array}$} & Mt & 10 & - & 20 & \multirow{3}{*}{-} \\
\hline & Et & 10 & 12 & 10 & \\
\hline & n-But & 15 & 20 & 10 & \\
\hline
\end{tabular}




\begin{tabular}{|c|c|c|c|c|c|}
\hline & $\mathrm{Ac}$ & 15 & - & 10 & \\
\hline \multirow{3}{*}{$\begin{array}{c}\text { Salmonella } \\
\text { typhi }\end{array}$} & $\mathrm{Mt}$ & 10 & 15 & 10 & \multirow{4}{*}{-} \\
\cline { 2 - 5 } & $\mathrm{Et}$ & 10 & - & 20 & \\
\cline { 2 - 5 } & $\mathrm{n}-\mathrm{But}$ & 10 & - & 10 & \\
\cline { 2 - 5 } & $\mathrm{Ac}$ & 10 & - & 20 & \\
\hline \multirow{3}{*}{$\begin{array}{c}\text { Bacillus } \\
\text { subtilis }\end{array}$} & $\mathrm{Mt}$ & 15 & 9 & 12 & \multirow{4}{*}{10} \\
\cline { 2 - 5 } & $\mathrm{Et}$ & 10 & 10 & 10 & \\
\cline { 2 - 5 } & $\mathrm{n}-\mathrm{But}$ & 10 & 13 & 10 & \multirow{3}{*}{16} \\
\cline { 2 - 5 } & $\mathrm{Ac}$ & 10 & 15 & 15 & \\
\hline \multirow{3}{*}{$\begin{array}{c}\text { Pseudomonas } \\
\text { aeruginosa }\end{array}$} & $\mathrm{Mt}$ & 12 & - & 10 & \\
\cline { 2 - 5 } & $\mathrm{Et}$ & 10 & - & 10 & \\
\cline { 2 - 5 } & $\mathrm{n}-\mathrm{But}$ & 10 & 15 & 10 & \\
\cline { 2 - 5 } & $\mathrm{Ac}$ & 10 & - & 15 & \\
\hline
\end{tabular}

$(-)=$ NZI - No Zone of Inhibition/Absence of susceptibility; Mt - Methanol; Et - Ethanol; n-But - n-Butanol; Ac - Acetone

Extract of Curcuma longa using Ethanol, Methanol, n Butyl alcohol and Acetone showed varying activities. A perusal of Table 1 indicates the varied activities as measured by zone of inhibition with extracts made with Ethanol on selected human pathogens such as Escherichia coli (NZI), $\beta$ haemo streptococci $(11 \mathrm{~mm})$, Klebsiella pneumoniae (NZI), Staphylococcus aureus $(12 \mathrm{~mm})$, Salmonella typhi (NZI), Bacillus subtilis $(10 \mathrm{~mm})$ and Pseudomonas aeruginosa (NZI) (Figure - 2). The zone obtained from inhibition measured with Methanol extract Escherichia coli $(20 \mathrm{~mm})$, $\beta$-haemo streptococci $(9 \mathrm{~mm})$, Klebsiella pneumoniae (7 $\mathrm{mm})$, Staphylococcus aureus (NZI), Salmonella typhi (15 $\mathrm{mm})$, Bacillus subtilis $(9 \mathrm{~mm})$ and Pseudomonas aeruginosa (NZI) (Figure - 1). Moreover, the zone of inhibition measured with n-Butyl alcohol extract on Escherichia coli $(25 \mathrm{~mm}), \beta$-haemo streptococci $(13 \mathrm{~mm}), \quad$ Klebsiella pneumoniae (NZI), Staphylococcus aureus $(20 \mathrm{~mm})$, Salmonella typhi (NZI), Bacillus subtilis $(13 \mathrm{~mm})$ and Pseudomonas aeruginosa $(15 \mathrm{~mm})$ (Figure - 3). In addition, the zone of inhibition measured with Acetone extract on Escherichia coli (NZI), $\beta$-haemostreptococci $(9 \mathrm{~mm})$, Klebsiella pneumoniae (NZI), Staphylococcus aureus (NZI), Salmonella typhi (NZI), Bacillus subtilis $(15 \mathrm{~mm})$ and Pseudomonas aeruginosa (NZI) (Figure - 4).

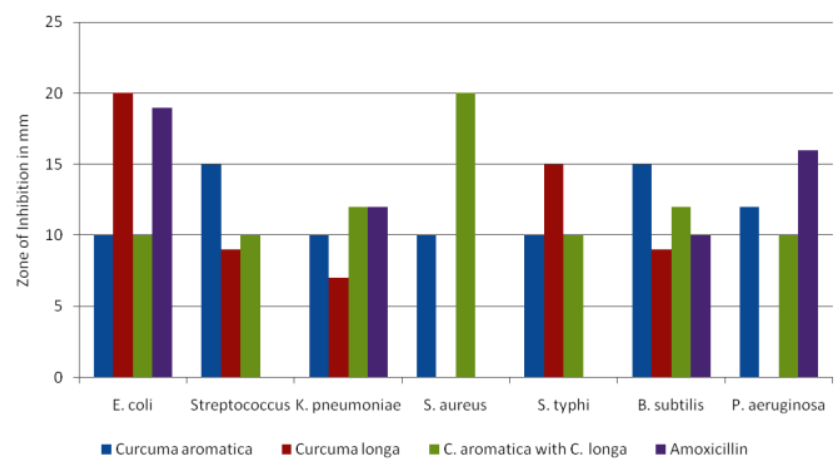

Figure 1. Sensitivity pattern of pathogenic bacteria with methanolic extract of Curcuma spp.

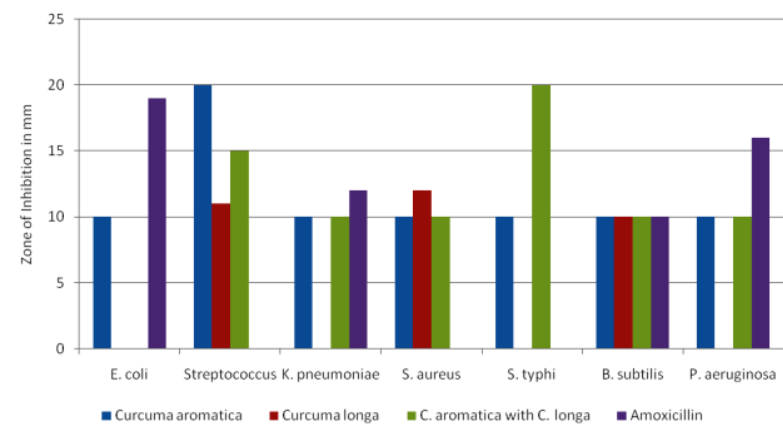

Figure 2. Sensitivity pattern of pathogenic bacteria with ethanolic extract of Curcuma spp.

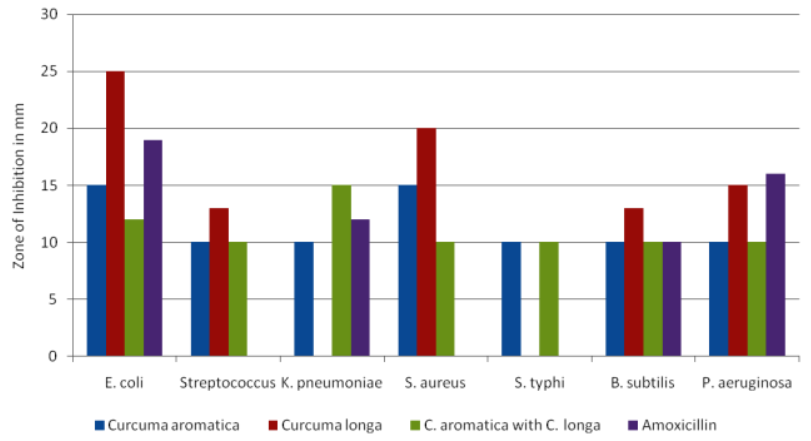

Figure 3. Sensitivity pattern of pathogenic bacteria with n-butanol extract of Curcuma spp.

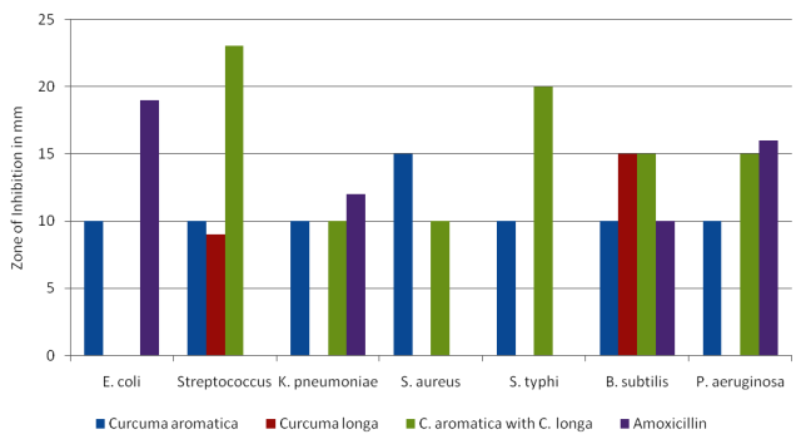

Figure 4. Sensitivity pattern of pathogenic bacteria with acetone extract of Curcuma spp.

Combined extracts of Curcuma aromatica and Curcuma longa using Ethanol, Methanol, n-Butyl alcohol, and Acetone showed varying activities. A perusal of Table 1 indicates the varied activities as measured by zone of inhibition with extracts made with Ethanol selected human pathogens such as Escherichia coli (NZI), $\beta$-haemo streptococci $(15 \mathrm{~mm})$, Klebsiella pneumoniae $(10 \mathrm{~mm})$, Staphylococcus aureus $(10 \mathrm{~mm})$, Salmonella typhi $(20 \mathrm{~mm})$, Bacillus subtilis $(10 \mathrm{~mm})$ and Pseudomonas aeruginosa (10 $\mathrm{mm}$ ) (Figure - 2). Moreover, the zone of inhibition 
measured with Methanol extract Escherichia coli $(10 \mathrm{~mm})$, $\beta$-haemo streptococci $(10 \mathrm{~mm})$, Klebsiella pneumoniae (12 $\mathrm{mm})$, Staphylococcus aureus $(20 \mathrm{~mm})$, Salmonella typhi $(10$ $\mathrm{mm})$, Bacillus subtilis $(12 \mathrm{~mm})$ and Pseudomonas aeruginosa $(10 \mathrm{~mm})$ (Figure -1$)$. The zone obtained from inhibition measured with n-butyl alcohol extract on Escherichia coli $(12 \mathrm{~mm}), \beta$-haemostreptococci $(10 \mathrm{~mm})$, Klebsiella pneumoniae $(15 \mathrm{~mm})$, Staphylococcus aureus $(10$ $\mathrm{mm})$, Salmonella typhi $(10 \mathrm{~mm})$, Bacillus subtilis $(10 \mathrm{~mm})$ and Pseudomonas aeruginosa $(10 \mathrm{~mm})$ (Figure - 3). In addition, the zone of inhibition measured with Acetone extract Escherichia coli (NZI), $\beta$-haemostreptococci (23 $\mathrm{mm})$, Klebsiella pneumonia (10 mm), Staphylococcus aureus $(10 \mathrm{~mm})$, Salmonella typhi $(20 \mathrm{~mm})$, Bacillus substilis $(15$ $\mathrm{mm})$ and Pseudomonas aeruginosa $(15 \mathrm{~mm})($ Figure -4$)$.

\section{Discussion}

The methanolic extract of $C$. longa showed better inhibition against $E$. coli than the standard antibiotic. Similarly, $C$. aromatica showed better inhibition of growth of $\beta$-haemo streptococci whereas the synergic effect of $C$. longa and $C$. aromatica against $K$. pneumonia is far better than antibiotic amoxicillin. Both $C$. longa and $C$. aromatica individually inhibit the growth of $S$. aureus than the standard antibiotic. C. longa inhibits the growth of $S$. typhi better than antibiotic however $C$. aromatica equally inhibits the growth of $S$. typhi with that of standard. The growth of $B$. substilis was inhibited by $C$. aromatica better than the standard antibiotic amoxicillin (Figure - 1). The ethanolic extract of $C$. aromatica showed better inhibition against $\beta$-haemo streptococci than the standard antibiotic. Similarly, all three had exhibits better inhibition of growth of S. aureus when standard antibiotic has no effect on this. Likewise, $C$. aromatica and the synergic effect of $C$. longa and $C$. aromatica against $S$. typhi also show far better inhibition when antibiotic amoxicillin has no effect on this pathogen. All three exhibited better inhibition of growth of B. substilis than the standard antibiotic amoxicillin (Figure -2 ).

The n-butanol extract of $C$. longa showed better growth inhibition than the antibiotic against E. coli. Similarly, all three had exhibits better inhibition of growth of $\beta$-haemo streptococci and $S$. aureus when standard antibiotic has no effect on this. The synergic effect of $C$. longa and $C$. aromatica against $K$. pneumonia is also far better than antibiotic amoxicillin. C. aromatica against $S$. typhi also show far better inhibition when antibiotic amoxicillin has no effect on this pathogen (Figure -3 ). The acetone extract of $C$. aromatica showed better inhibition of $S$. aureus and $S$. typhi when antibiotic amoxicillin has no effect on these pathogens. Similarly, the synergic effect of $C$. longa and $C$. aromatica against $\beta$-haemo streptococci is also far better than antibiotic amoxicillin (no effect). All three had exhibits better inhibition of growth of $B$. substilis than the standard antibiotic amoxicillin (Figure -4 ).
The development of bacterial resistance to the available antibiotics is a matter of discussion in an era of modern medicines and increasing popularity of traditional medicine has led researchers to investigate the antibacterial compounds in plants $[1,12]$. It was reported that the use of alternative medicinal therapy had increased the interest of pharmacologists and herbalists over the past decade. Natural products from plants may offer new agents for antimicrobial use. A special feature of higher plants is their capacity to produce a large number of organic chemicals of high structural diversity the so called secondary metabolites [13]. It was found out that turmeric is well known for their antimicrobial properties and has been aptly known as the village dispensary for the past 2000 years [14,1]. It was reported that rhizome of Curcuma longa is locally called as zerdecal It is traditionally used in the treatment of infectious diseases, hepatitis and liver diseases [15]. This plant increases the bile level and makes stomacahes to disappear. It was documented that Turmeric extract and the essential oil of Curcuma longa inhibit the growth of a variety of bacteria, parasites and pathogenic fungi. A study of chicks infected with the caecal parasite Eimera maxima demonstrated that diets supplemented with 1 - percent turmeric resulted in a reduction in small intestional leison scores and improved weight gain [16].

The crude extracts of curcuminoids and essential oil of Curcuma longa varieties were studied for their antibacterial activity against four bacterial strains viz., Bacillus subtilis, Bacillus macerans, Bacillus licheniformis and Azotobacter using agar well diffusion method. Ethanol was used for the extraction of curcuminoids. Both curcuminoids and oil showed zone of inhibition against all tested strain of bacteria. Among all the bacterial strains Bacillus subtilis was the most sensitive to turmeric extracts of curcuminoids and oil. The MIC value for different strains and varieties ranged from 3.0 to $20.6 \mathrm{~mm}$ in diameter [17].

Kasur curcuminoid showed that Bacillus subtilis, Bacillus macerans, Bacillus lichenformis and Azotobacter were inhibited at all concentrations and Kasur oil was also effective against all tested strains while Bacillus licheniformis was resistant only at lower concentration ranged from 4 to $10 \mathrm{mg} / \mathrm{ml}$. kasur Curcuminoids showed higher MIC against only Bacillus subtilis as compared to all other tested organisms. They concluded that faisalabad variety showed antibacterial activity against all tested microorganisms and its curcuminoid had large MIC than oil. Faisalabad curcuminoids gave higher zone of inhibition against Bacillus subtilis $(12.2 \mathrm{~mm})$ and followed by Bacillus licheniformis $(8.1 \mathrm{~mm})$, Bacillus macerans $(7.6 \mathrm{~mm})$ and Azotobacter $(7.1 \mathrm{~mm})$. Its oil also gave higher MIC against Bacillus subtilis $(10.0 \mathrm{~mm})$ and followed by Bacillus licheniformis $(7.0 \mathrm{~mm})$, Azotobacter $(6.0 \mathrm{~mm})$ and 
Bacillus macerans $(5.0 \mathrm{~mm})$. Bannu curcuminoid and oil was also effective against tested microorganisms at higher concentrations. It gave higher MIC against Bacillus subtilis $(7.0 \mathrm{~mm})$ and lower MIC against Azotobacter $(5.3 \mathrm{~mm})$. Bannu oil also showed higher MIC against Bacillus subtilis (8.0 mm0 and lower MIC against Azotobacter (5.5 mm) [17].

It was documented that the components of turmeric are named curcuminoids, which include mainly curcumin (diferuloyl methane), demethoxy curcumin and bisdemethoxycurcumin. Curcumin is the most important fraction which is responsible for the biological activities of turmeric. The melting point of curcumin, $\mathrm{C}_{2} \mathrm{H}_{2} \mathrm{O}_{6}$, is $184^{\circ} \mathrm{c}$. It is soluble in Ethanol and Acetone, but insoluble in Water. Curcumin $95 \%$, a potent antioxidant is believed to be the most bioactive and soothing portion of the herb turmeric and posses the properties like antioxidant, anti - inflammatory, antibacterial and antifungal effects. It contains a mixture of powerful antioxidant phytonutrients known as curcuminoids and inhibits cancer at initiation, promotion and progression stages of tumour development [18]. Curcumin was first isolated in 1815 [19]. Its chemical structure was determined by Roughley and Whiting (1973) [20]. In the molecule of curcumin, the main chain is aliphatic, unsaturated and the aryl group can be substituted or not. Curcuma longa oil was tested against cultures of Staphylococcus albus, Staphylococcus aureus and Bacillus typhosus, inhibiting the growth of Staphylococcus albus and Staphylococcus aureus in different concentrations.

It was cited that the antibacterial activities of 1,4-Dioxan and DMF extracts of Ginger, Mango ginger and Turmeric against Bacillus subtilis. The 1,4 - Dioxan extract of Mango ginger was highly active aganst Bacillus subtilis, followed by Turmeric and Ginger. The Dimethyl formamide (DMF) extract of Mango ginger also showed the highest activity followed by Turmeric and Ginger. The mixture of 1,4 Dioxan extracts of Turmeric and Mango ginger showed the highest activity, followed by Ginger and Mango ginger and Ginger and Turmeric. Similar activity was found with the mixture of DMF extracts. As well as the astibacterial activities of 1,4 - Dioxan and DMF extracts of Ginger, Mango ginger and Turmeric against Staphylococcus aureus. The 1,4 - Dioxan extract of Mango ginger showed the highest activity followed by Turmeric and Ginger. However, the DMF extract of all the 3 spices did not show any activity. The mixture of 1,4 - Dioxan extracts of Ginger and Mango ginger showed the highest activity, followed by Turmeric and Mango ginger, Ginger and Turmeric. Here too the mixture of DMF extracts did not show any activity. It was reported that the antibacterial activities of four synthetic compounds, i.e. $\mathrm{HC}-1, \mathrm{HC}-2, \mathrm{HC}-3$ and $\mathrm{HC}-4$ in 1,4Dioxan as well as in DMF extracts against Escherchia coli. In 1,4 - Dioxan, $\mathrm{HC}-2$ and $\mathrm{HC}-3$ showed the highest activity followed by $\mathrm{HC}-1$ while $\mathrm{HC}-4$ had the lowest activity. The synthetic compound HC - 1 in DMF showed very little activity against Escherchia coli while the other compounds did not show any activity. The antibacterial activity of synthetic compounds of $\mathrm{HC}-3$ in 1,4 Dioxan and DMF extracts against Bacillus subtilis showed highest activity. The antibacterial activity of $\mathrm{HC}-2$ in 1,4 Dioxan and DMF extracts against Staphylococcus aureus showed highest activity [21].

It was concluded that the antibacterial activities of heated and unheated extracts of Ginger, Mango ginger and Turmeric were almost identical and the heated extracts also showed slightly higher activity compared to unheated extracts. Mixtures of heated extracts of Ginger, Mango ginger and Ginger and Turmeric were slightly more active against Bacillus subtilis compared to those of Turmeric and Mango ginger. The antibacterial activity of mixture of spices and peels showed good antibacterial activity against Escherchia coli. The activity of heated extracts was greater than that of unheated extracts. The maximum activity was that of peels followed by the 3 spices mixtures i.e., Ginger Turmeric and Ginger Mango ginger and Turmeric mango ginger. Heated and unheated extracts of Ginger were more active against Staphylococcus aureus compared to the heated and unheated extracts of Mango ginger and heated and unheated extracts of Turmeric did not show any activity against Staphylococcus aureus. The mixture of heated extracts of Ginger Turmeric displayed the highest activity, followed by the mixture of Ginger Mango ginger and the mixture of heated peel extracts. When the extract of Turmeric mango ginger was considered both heated and unheated extracts failed to show any activity against Staphylococcus aureus [22].

It was explained that the antibacterial activity of turmeric on pathogenic strains of Gram positive bacteria, Staphylococcus aureus and clinical isolate and Staphylococcus epidermidis and Gram negative bacteria Escherichia coli and clinical isolate, Pseudomonas aeruginosa and clinical isolate, Salmonella typhimurium by zone of inhibition assay [23]. It was analysed that Turmeric consists of $3-5 \%$ curcuminoids. Curcumin is the most important fraction which is responsible for the biological activities of turmeric. The melting point of curumin is $184^{\circ} \mathrm{C}$ and it is soluble in Ethanol and Acetone. It exists in solution as keto-enol tautomers [24]. It was reported that for the last few decades extensive work has been done to establish the biological activities and pharmacological action of turmeric and its extracts [24-25].

It was cited that the antimicrobial effect of turmeric, ginger root and linseed against test microorganisms, only the alcoholic extract was tested, as alcohol was found to be better solvent for extraction of antimicrobially active substances compared to Water and Hexane [26]. However, some reported that the antibacterial effect of Curcuma longa showed better results with different fractions of solvent 
against UTI isolates [27]. But some reported that the essential oil fraction from turmeric possess significant $(\mathrm{P}<0.001)$ antibacterial activity at very low concentration $(20$ $\mu \mathrm{g} / \mathrm{disc}$ ) on pathogenic Gram positive Staphylococcus aureus bacteria [28].

It was reported that the hydro ethanolic extract of Curcuma zeodaria and Curcuma aromatica rhizomes were found to have potent antimicrobial activity against Bacillus cereus at $1000 \mu \mathrm{g} / \mathrm{ml}$ and showed moderate activity against Klebsiella pneumoniae and Candida albicans. In the case of MIC, hydro ethanolic extract of Curcuma aromatica inhibited Bacillus cereus at $15.625 \mu \mathrm{g} / \mathrm{ml}$, Klebsiella pneumoniae was inhibited at $62.5 \mu \mathrm{g} / \mathrm{ml}$ and Candida albicans at $125 \mu \mathrm{g} / \mathrm{ml}$. Hydro ethanolic of Curcuma zeodaria inhibited Bacillus cereus at $31.25 \mu \mathrm{g} / \mathrm{ml}$ where as Klebsiella pneumoniae and Candida albicans were inhibited at $125 \mu \mathrm{g} / \mathrm{ml}$ [29].

\section{CONCLUSION AND FUTURE SCOPE}

Turmeric has an important role as an antimicrobial agent against multi drug resistant bacteria. They are natural, cheap, easily available and safe. Due to increase in antibiotic resistance, they can be used for prevention of many infections such as diarrheal diseases (caused by E.coli), skin infections etc. Rhizomatous extracts of Curcuma from wild areas like Western Ghats can be a possible source to obtain new and effective herbal medicines to treat disease caused by multiple drug resistant strains of bacteria. However it is necessary to isolate their active constituents from different ecotypes and determine their toxicity, side effects and pharmaco-kinetic properties.

\section{REFERENCES}

[1] I. Chattopadhyay, K. Biswas, U. Bandyopadhyay, R.K. Banerjee, "Turmeric and curcumin: Biological actions and medicinal applications", Curr. Sci., Vol.87, pp.44-53, 2004.

[2] T. Rudrappa, H.P. Bais, "Curcumin, a known phenolic from Curcuma longa, attenuates the virulence of Pseudomonas aeruginosa PAO1 in whole plant and animal pathogenicity models", Journal of Agriculture and Food Chemistry, Vol.56, pp.1955-1962, 2008.

[3] A.E. Mohamed, A.F. Abdel-Aziz, E. M. El-Sherbiny, R.M. Mors, "Anti-diabetic effect of Aloe vera juice and evaluation of thyroid function in female diabetic rats", Bioscience Research, Vol.6, pp.28-34, 2009.

[4] I.S. Villagas, S. Fidalgo, L.C. Alacon, "New mechanisms and therapeutic potential of curcumin for colorectal cancer", Molecular Nutrition and Food Research, Vol.52, pp.1040-1061, 2008.

[5] S.A. Antunes, S.R. Weber, L. Schittler, G.A. Gomes, "Synergistic and antimicrobial properties of commercial turmeric (Curcuma longa) essential oil against pathogenic bacteria", Ciênc Tecnology Aliment Campinas, Vol.32, pp.525-530, 2012.

[6] A. Apisariyakul, N. Vanitanakom, D. Bunddhasukh, "Antifungal activity of turmeric oil extracted from Curcuma longa", Journal of Ethanopharmacology, Vol.49, pp.163-169, 1995.

[7] A.K. Tripathi, V. Prajapati, N. Verma, J.R. Bahl, R.P. Bansal, S.P.S. Khanuja, S. Kumar, "Bioactivities of the leaf essential oil of
Curcuma longa (var. Ch-66) on three species of stored-product beetles (Coleoptera)", Journal of Economics Entomology, Vol.95, pp.183-189, 2002.

[8] A. Parvin, J. Akter, M.M. Hassan, N. Biswas, "Study on the comparative antibacterial activity of Polyalthia longifolia (Debdaru) leaf extracts to some selective pathogenic bacterial strains", International Journal of Biosciences, Vol.3, pp.17-24, 2013.

[9] M.A. Morshed, A. Uddin, R. Saifur, A. Barua, A. Haque, "Evaluation of Antimicrobial and Cytotoxic properties of Leucas aspera and Spilanthes paniculata", International Journal of Biosciences, Vol.1, pp.7-16, 2011.

[10] N. Fayzunnessa, M.A. Morshed, A. Uddin, A. Parvin, R. Saifur, "In vivo study on the efficacy of hypoglycemic activity of Spirulina plantesis in long evan rats", International Journal of Biomolecules and Biomedicine, Vol.1, pp.27-36, 2011.

[11] H.J.D. Dorman, S.G. Deans, "Antimicrobial agents from plants: antibacterial activity of plant volatile oils", Journal of Applied Microbiology, Vol.88, pp.308-316, 2000.

[12] N. Sharma, "Antibacterial Activity of Fresh Juices of Lemon, Onion, Bottle Gourd and Tomato Against Multiple Drug Resistant Bacteria such as E. Coli, Staphylococcus, Bacillus, Klebsiella and Salmonella", International Journal of Scientific Research in Biological Sciences, Vol.2, Issue.2, pp.16-20, 2015.

[13] J.P. Robinson, V. Balakrishnan, J.S. Raj, S.J. Britto, "Antimicrobial activity of Alpinia calcarata Rosc. and characterization of new $\square, \square$ unsaturated carbonyl compound", Advances in Biological Research, Vol.3, Issue.5-6, pp.184-187, 2009.

[14] R. Harikrishnan, C.N. Rani, C. Balasundaram, "Hematological and biochemical parameters in common carp, Cyprinus carpio, following herbal treatment for Aeromonas hydrophila infection", Aquaculture, Vol.221, pp.41-50, 2003.

[15] T. Baytop, "Therapy with medicinal plants in Turkey (past and present)", Istanbul University, 1984.

[16] P.C. Allen, H.D. Danforth, P.C. Augustine, "Dietary modulation of avian coccidiosis", Int. J. Paracitol. Vol.28, Issue.7, pp.1131$1140,1998$.

[17] S. Naz, S. Jabeen, S. Ilyas, F. Manzoor, F. Aslam, A. Ali, "Antibacterial activity of curcuma longa varieties against different strains of bacteria", Pak. J. Bot., Vol.42, Issue.1, pp.455-462, 2010.

[18] N. Chainani-Wu, "Safety and anti-inflammatory activity of curcumin: a component of turmeric (Curcuma longa)", J. Altern. Complement Med., Vol.9, pp.161-168, 2003.

[19] H.A. Vogel, J. Pelletier "Chemische Untersuchung der Gilbwurzel (Kurkume)", J. Pharma. Vol.7, pp.20, 1815.

[20] P.J. Roughley, A. Donald, D.A. Whiting, "Experiments in the biosynthesis of curcumin", J. Chem. Soc., Perkin Trans., Vol.1, pp.2379-2388, 1973.

[21] H. Chandarana, S. Baluja, S.V. Chanda, "Comparison of antibacterial activities of selected species of Zingiberaceae family and some synthetic compounds", Tur. J. Biol., Vol.29, 83-97, pp.2005.

[22] K. Paech, M.V. Tracey, "Modern Methods of Plant Analysis", Springer Verlag, Berlin, vol. III, pp. 626-654, 1995.

[23] F. Payton, P. Sandusky, W.L. Alworth, "NMR study of the solution structure of curcumin", J. Nat.Prod., Vol.70 Issue.2, pp.143-146, 2007.

[24] J. Joshi, S. Ghaisas, A. Vaidya, R. Vaidya, D.V. Kamat, A.N Bhagwat, S. Bhide, "Early human safety study of turmeric oil (Curcuma longa oil) administered orally in healthy volunteers", $J$. Assoc. Physicians India, Vol.51, pp.1055-1060, 2003.

[25] P. Chirangini, G.J. Sharma, S.K. Sinha, "Sulfur free radical reactivity with curcumin as reference for evaluating antioxidant properties of medicinal Zingiberales",. Journal of 
Environnemental Pathology, Toxicology and Oncology, Vol.23, pp.227-236, 2004.

[26] I. Ahmad, Z. Mehmood, F. Mohammad, "Screening of some Indian medicinal plants for their antimicrobial properties", $J$. Ethnopharmacol., Vol.62, pp.183-193, 1998.

[27] N. Gul, T.Y. Mujahid, N. Jehan, S. Ahmad, "Studies on the antibacterial affect of different fractions of Curcuma longa against Urinary tract Infection isolates", Pakistan J. Biol. Sceinces, Vol.7, Issue.12, pp.2055-2060, 2004.

[28] R. Singh, R. Chandra, M. Bose, P.M. Luthra, "Antibacterial activity of Curcuma longa rhizome extract on pathogenic bacteria", Current Science, Vol.83, Issue.6, pp.737-740, 2002.

[29] A.R. Srividya, A.K. Yadav, S.P. Dhanabal, "Antioxidant and Antimicrobial Activity of Rhizome of Curcuma aromatica and Curcuma zeodaria, Leaves of Abutilon indicum", Archives of Pharmaceutical Sciences and Research, Vol.1, Issue.1, pp.14-19, 2009.

\section{AUTHORS PROFILE}

Mr. R. Suresh pursed B.Sc., M.Sc. and M.Phil. Botany from AVVM Sri Pushpam College, Poondi, affiliated to Bharathidasan University, and Ph.D. Botany from Manonmaniam Sundaranar University, Thirunelveli (Pursuing) through Scott Christian College (Autonomous), Nagercoil, India. He has cleared State Level Eligibility Test (SLET) for Lecturership. He has

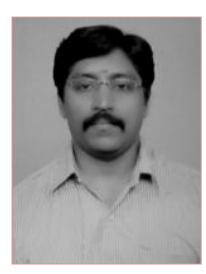
worked in Department of Botany, RKM Vivekananda College, Mylapore, Chennai; in Department of Microbiology, Sri Venkateshwara Arts and Science College, Peravurani; in Department of Botany, AA Government Arts College, Namakkal, in Department of Microbiology, Sri Venkateshwara Arts and Science College, Peravurani. $\mathrm{He}$ is a member of the International Association for Ecology (INTECOL). He has published 3 books and 10 research papers in reputed international journals and conferences and it's also available online. His main research work focuses on Plant biotechnology and Microbiology. He has 15 years of teaching experience and 10 years of research experience.

Dr. S. Thampi Raj pursed B.Sc. from Nesamony Memorial Christian College in 1992, M.Sc., M.Phil. from AVVM Sri Pushpam College, Poondi, affiliated to Bharathidasan University, in 1994 \& 1996, and Ph.D. from Central Marine Fisheries Research Institute, Vizhinjam in 2003. $\mathrm{He}$ is currently working as Assistant Professor in Department of Botany, Scott Christian College (Autonomous), Nagercoil, India. He has

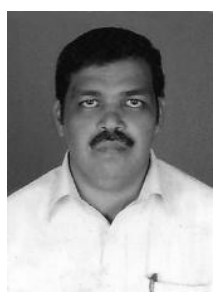
published more than 50 research papers in reputed international journals including Thomson Reuters (SCI \& Web of Science) and conferences and conferences and it's also available online. His main research work focuses on Microbiology. He has 15 years of teaching experience and 25 years of research experience.

Dr. A. Stephen pursed B.Sc., M.Sc. and Ph.D. Botany from MCC, Chennai. He has worked in the School of Liberal Arts and Sciences, TransDisciplinary University, Bengaluru, India; Department of Botany, RKM Vivekananda College, Mylapore, Chennai; in Department of Botany, Madras Christian College (Autonomous), Chennai, India; in
Department of Ecology, French Institute of Pondicherry, Puducherry, India; in Central Institute of Medicinal and Aromatic Plants, Resource centre, Bangalore, India; in Scarascia Mugnozza Genetic Resources Centre, MSSRF, Chennai, India. He is a Life member of International Society of Plant Morphologists (ISPM), Senior Member, Asia-Pacific Chemical, Biological \& Environmental Engineering Society (APCBEES) and a life Member of the International Association for Ecology (INTECOL). He has published more than 40 research papers in reputed international journals including Thomson Reuters (SCI \& Web of Science) and conferences and it's also available online. His main research work focuses on biodiversity, forest ecology, palynology, palaeoecology, biochemistry, seed ecophysiology and water quality analysis. He has 5 years of teaching experience and 15 years of research experience. 